\title{
Przyjemność niejedno ma imię \\ Sprawozdanie z konferencji naukowej „Przyjemności duchowe i cielesne w kulturze na przestrzeni dziejów", Lublin, 6 listopada 2015 r.
}

6 listopada 2015 r. Zakład Historii Kultury Instytutu Kulturoznawstwa UMCS we współpracy z Sekcją Kulturoznawczą Koła Naukowego Doktorantów Wydziału Humanistycznego UMCS zorganizował ogólnopolską konferencję naukową „Przyjemności duchowe i cielesne w kulturze na przestrzeni dziejów”.

Celem konferencji była wspólna refleksja i dyskusja nad przyjemnościami cielesnymi i duchowymi w szerokiej perspektywie przemian historyczno-kulturowych na przestrzeni dziejów. Konferencja była próbą przedstawienia, jak $\mathrm{w}$ różnych kontekstach, kulturach i w różnym czasie historycznym funkcjonowała kategoria przyjemności - jak zmieniały się jej znaczenie i definicje.

Spotkanie miało charakter interdyscyplinarny. Wzięli w nim udział zainteresowani tą problematyką kulturoznawcy, antropolodzy, historycy sztuki i historycy kultury, folkloryści, archeolodzy oraz przedstawiciele innych dyscyplin humanistycznych z różnych ośrodków naukowych: Poznania, Krakowa, Warszawy, Bydgoszczy, Olsztyna, Rzeszowa, Opola, Torunia, Łodzi i Lublina. W konferencji wzięli też udział pracownicy Muzeum Etnograficznego w Poznaniu oraz Agencji Służby Społecznej w Warszawie.

Wygłoszono 30 referatów, które zostały zaprezentowane w kilku sekcjach tematycznych. Nie sposób wymienić i streścić wszystkie referaty, dlatego z konieczności zostaną zaprezentowane wybrane wystąpienia. Uroczystego otwarcia konferencji dokonała prof. dr hab. Małgorzata Karwatowska, prodziekan ds. Ogólnych Wydziału Humanistycznego UMCS, podkreślając znaczenie i ważność problematyki podjętej podczas konferencji. Referaty rozpoczynające były 
poświęcone przyjemności płynącej z aktu komunikowania się z drugim człowiekiem oraz z Bogiem. Dr hab. Marta Wójcicka (UMCS) wskazała funkcje przyjemności w odniesieniu do schematu komunikowania Roberta Jakobsona, analizując m.in. przyjemność „wpisaną” w tekst oraz komunikaty pełniące funkcje ludyczne. Z wystąpieniem tym korespondował referat mgr Beaty Fijołek (UMCS), poświęcony ucztom dejponosofistów. Referentka na podstawie Uczty mędrców Atenajosa, Uczty Platona oraz Biblii nakreśliła porównawczy obraz biesiad starożytnych, skupiając się na trzech aspektach osiągania przyjemności: jedzeniu, miłości oraz zjednoczeniu z Bogiem.

Po zakończeniu części plenarnej obrady toczyły się w dwóch równoległych sekcjach: literaturoznawczej i historyczno-etnograficznej, natomiast ostatnia była poświęcona sztuce. Wystąpienia historyków kultury odznaczały się bogactwem poruszanych wątków, ukazując tym samym skalę istotnych problemów i zagadnień związanych z poruszaną tematyką. Wypowiedzi były uszeregowane chronologicznie. Dużym zainteresowaniem cieszyło się wystąpienie mgr Agnieszki Stempin z Muzeum Archeologicznego w Poznaniu, która zaprezentowała rolę gry w szachy w średniowieczu. W świetle analizy badaczki gra mogła dostarczać wiele przyjemnych doznań związanych nie tylko z satysfakcją, jaką daje wygrana, czy posiadanie cennych przedmiotów, lecz także z poznawaniem nowych obszarów kulturowych i estetycznych. Prof. dr hab. Marek Radoch (UWM) zapoznał słuchaczy z przyjemnościami, jakie czekały na przybyszów w zamku krzyżackim w Malborku. Badacz wykazał, że wbrew powszechnej opinii na temat surowości średniowiecznych zamków w Malborku i w innych zamkach krzyżackich nie brakowało wygód. Oprócz dobrego jedzenia na gości czekały inne luksusy owych czasów (m.in. łaźnia parowa, polowania, turnieje, występy muzyczne wagantów). Praktyki umilania czasu w okresie epidemii dżumy w Polsce w XVI w. interesowały z kolei mgr Agnieszkę Bywalec (UPJP). Wspólnym ogniwem dwóch innych referatów z tej sekcji były przyjemności podniebienia i zmiana upodobań smakowych. Mgr Ewa Sztomberska (KUL) omówiła rolę słodyczy w XVI i XVII w., dokonując również porównania między dawnymi i współczesnymi konfektami, a mgr Barbara Hołub (UMCS) zapoznała słuchaczy z historią „narodzin” cydru i rewolucją smakową, jaką wywołał ten napój alkoholowy. Natomiast referat badaczki z Państwowej Akademii Nauk, mgr Agaty Błoch, o kochankach Pedra I - cesarza Brazylii, jak się później okazało, zapoczątkował ożywioną dyskusję na temat postrzegania przez Brazylijczyków miłości fizycznej.

Uzupełnieniem rozważań o przyjemnościach życiowych z perspektywy historycznej mogą być zalecenia z XVIII-wiecznego dzieła Philiberta-Josepha Le Roux Dictionnaire comique, satyrique, critique, burlesque, libre et proverbial 
(Stownik komiczny, satyryczny, zawierajacy terminy z burleski i przysłowia), które w swoim referacie przedstawiła dr Małgorzata Posturzyńska-Bosko (UMCS). Prelegentka nakreśliła, jakimi cechami charakteru i zachowania - w opinii autora słownika - odznacza się człowiek zadowolony z życia, który wszelkimi zmysłami chłonie życie i wszelkie jego aspekty.

Analizy historyczne uświadomiły uczestnikom konferencji, że pragnienie odczuwania różnego rodzaju przyjemności, jak również ich doświadczanie, towarzyszy człowiekowi od zarania dziejów. Na przestrzeni wieków zmieniło się samo postrzeganie przyjemności, jednakże poszukiwanie i jej odnajdywanie wydaje się szczególnie istotnym motywem działania zarówno jednostek, jak i całych społeczności.

W panoramie analiz kulturowego obrazu przyjemności dość liczne były referaty omawiające to zagadnienie w ujęciu literaturoznawczym. W pierwszej sekcji tego bloku swoje referaty zaprezentowali m.in. dr Estera Głuszko-Boczoń (URz), mgr Kamil Dźwinel (UMK) i mgr Konrad Małecki (UŁ). Największe zainteresowanie wzbudził referat dr Estery Głuszko-Boczoń zatytułowany „Przyjemność i pasja jako źródło obsesji w Pannie de Scudery E.T.A. Hoffmanna i Pachnidle P. Süskinda”. Autorka skupiła swoją uwagę na tym, czy przyjemność może stać się obsesją i czy pasja może doprowadzić do obłędu. Z kolei mgr Konrad Małecki podjął próbę zdefiniowania pojęcia „przyjemność” w twórczości Oskara Wilde’a, obnażając złożoność zagadnienia i bogactwo zjawisk mieszczących się w tej kategorii. Oboje referenci ukazali drogę przeradzania się przyjemności (zarówno duchowej, jak i fizycznej) w obsesję.

Po przerwie w sekcji o tej samej tematyce wygłoszono cztery referaty. Spośród nich duże zainteresowanie wzbudziły teksty mgr. Piotra Kulpy (UKW) i dr Anety Jurzystej (URz). Badacz z Uniwersytetu Kazimierza Wielkiego w Bydgoszczy na podstawie twórczości Bolesława Prusa i Wincentego Łosia przekonywał, że „treścią życia jest ruch”, prezentując literackie przykłady przyjemności, jakich potrafi dostarczyć jazda rowerem. Dr Aneta Jurzysta analizie poddała motyw rozkoszowania się jadłem i trunkami w literaturze niemieckiej, ukazując, że pełnią one różnorodne funkcje i role. Wystąpienie poświęcono najbarwniejszym przykładom rozkoszowania się potrawami i ucztowania w twórczości Johanna Wolfganga von Goethego, Christa Wolfa, Heinricha Bölla, Siegfrieda Lenza czy Güntera Grassa i Thomasa Manna.

W sekcji etnograficznej także podejmowano interesujące i inspirujące problemy dotyczące konotacji terminów „przyjemność” i „przyjemny”. Obrady rozpoczęła dr Agata Rybińska (UMCS) referatem „Przyjemności w kulturze żydowskiej - pomiędzy religią a folklorem”. Na przykładzie szabatu oraz świąt Chanuki i Purim autorka zobrazowała, jakie przyjemności wiązały się i wiążą 
ze świętowaniem, zarówno w obrębie kultu, jak i ludowej tradycji żydowskiej (i paraleli w kulturze chrześcijańskiej), w kulturze duchowej i materialnej. Wątek przyjemności czasu świątecznego i kontaktu z sacrum w tradycji Żydów aszkenazyjskich kontynuowała w swoich badaniach mgr Joanna Matyjasek (UMCS). Kolejna prelegentka, mgr Olga Kielak (UMCS), skupiła się na polskiej kulturze ludowej, prezentując niezwykle interesujące studium symboliki psa w ludowych pieśniach miłosnych.

Zagadnienie przyjemności duchowych i cielesnych okazało się szczególnie atrakcyjne dla historyków sztuki. Dr Ewa Rybałt (UMCS) spojrzała na przyjemność z perspektywy humanistycznej teorii zmysłów wzroku i słuchu na przykładzie obrazów Tycjana. Według prelegentki, przyjemność oglądania natury, np. nagiego ciała kobiety, miała cele dydaktyczne, służące chrześcijańskiej wizji małżeństwa, ale także idei pax venetae. Wspólną osią pozostałych referatów było ukazanie na wybranych przykładach z historii sztuki, w jaki sposób artyści, posługując się różnym technikami, zapraszali do doznawania przyjemności, a jednocześnie ukazywali bezpośrednio bądź w zakamuflowany sposób przyjemność przeżytą, strawioną, doznawaną. Dr Paweł Maciąg (KUL, PL) skupił uwagę na twórczości Hieronima Boscha, mgr Elwira Bolek (UMCS) wykorzystała teatralne i operowe plakaty Rafała Olbińskiego, mgr Rafał Piekarz (UW) zaś pochylił się nad sztuką Kampu.

Mgr Anna Kowalska (UJ) podjęła się niełatwego zadania zbadania pocałunku z perspektyw różnych dziedzin nauki, m.in. antropologii, kulturoznawstwa, psychologii ewolucyjnej, neuropsychologii, nauk kognitywnych, antropoetologii, socjobiologii. Z racji obszerności tematu cel ten nie został osiągnięty, jednakże prelegentka zobowiązała się do zaprezentowania pełnych wyników badań w publikacji.

Swoistym podsumowaniem podjętej problematyki był referat dotyczący problemu doświadczenia przez człowieka całości i pełni w czasach współczesnych. Mgr Katarzyna Mirocha (UJ) w swojej argumentacji podjęła próbę udowodnienia tezy, że poczucie tzw. pełni nie jest już realne, ponieważ niewiele ma wspólnego z pragmatycznym przystosowywaniem się do efemerycznych doznań i przyjemności. Człowieka XXI w., zdaniem badaczki, charakteryzuje refleksyjność, która utrudnia mu doznanie poczucia harmonii własnego „ja” ze światem, mając negatywny wpływ na jego kondycję psychiczną.

Konferencja była doskonałą okazją do dyskusji i wymiany poglądów na temat pragnienia i odczuwania przyjemności, metod i sposobów ich zaspokojenia oraz konsekwencji z tego wynikających. Wielość, różnorodność i istotność poruszanych podczas obrad problemów oraz wywołane dyskusje świadczą o potrzebie badania tego rodzaju doświadczenia, które nieustannie towarzyszy człowiekowi. 
Pobrane z czasopisma Artes Humanae http://arteshumanae.umcs.pl Data: 26/04/2023 16:05:05

Wspomniane i omówione wystąpienia stanowią reprezentatywną próbę interdyscyplinarnej i ważkiej refleksji podjętej podczas sesji. Z dorobkiem konferencji będzie można się zapoznać w publikacji pokonferencyjnej. Wydanie monografii jest planowane na trzeci kwartał $2016 \mathrm{r}$. 
Pobrane z czasopisma Artes Humanae http://arteshumanae.umcs.pl Data: 26/04/2023 16:05:05 